\title{
Functions and Uses of the Sarawak Malay Proverbs
}

\author{
Abang Patdeli bin Abang Muhi \\ Dewan Bahasa dan Pustaka, Malaysia
}

\begin{abstract}
Proverbs are the integral part of spiritual treasures of the culture and language of the people, the age-old wisdom and skills used by them. Proverbs are also an interesting pieces of popular wisdom and tradition belonging to any culture, which help us to foreground the values a shared beliefs held by a speech community. By applying Sperber and Wilson's Relevance Theory, this dissertation research aims to analyze the functions and uses of Sarawak Malays' proverbs which up to now received very little attention amongst the local researchers. Besides, the application of this theory has successfully explains how the proverbs allow the speaker to express his or her intentions, feelings and insights in an implicit way and tacit manner. The findings demonstrate that the main functions of the Sarawak Malays' proverbs are criticism, advice, warning, educating, sarcasm and insinuation which also reflect the wisdoms and wits of the Sarawak Malays. This research also offered an explanation of how the often ironical, metaphorical and figurative nature of the proverbs significantly affects their understanding. In addition, I have also studied the use of ellipsis in the familiar proverbs as well as found out the existence of various types of proverbs amongst the Sarawak Malays' community. Ultimately, the conclusions of the research are to attain a better comprehension of the functions and uses of the Sarawak Malays' proverbs
\end{abstract}

\section{Introduction}

Most probably, only a handful of us know about the existence of the Malay community in Sarawak. Furthermore, compared to other ethnic groups in the state, particularly the Ibans, the Sarawak Malay community apparently does not capture the interest of the local as well as foreign researchers, especially among the sociologists and anthropologists.

Since this paper deals with the Sarawak Malays' proverbs, it is relevant indeed to furnish a brief socio-cultural background of the community. The Malays are the second largest ethnic group in Sarawak after the Ibans, and they are different from the Malays in the Peninsular Malaysia or Sabah in most aspects except for their religion. The Sarawak Malays have their own local language and dialects. According to Abang Yusuf Puteh (1998), their cultures and outlook on life generally are almost totally different too from the Peninsula Malays.

Abang Yusuf Puteh (1998:8) quoted Alfred Russel Wallace's, observation on Sarawak Malays his visit to Santubong etc .in 1885: "In character the Malay is impassive. He exhibits a reserve, diffidence, and even bashfulness, which is in some degree attractive, and leads the observer to think that the ferocious and bloodthirsty character imputed to the race must be grossly exaggerated. He is not demonstrative. His feelings of surprise, admiration, or fear, are never openly manifested, and probably not strongly felt. He is slow and deliberate in speech, and circuitous in introducing the subject he has come expressly to discuss. These are the main features of his moral nature, and exhibit themselves in every action of his life...."

Distinctly language defines culture, and proverbs as an element of language essentially encapsulate the values, beliefs and wisdom of the community. The Sarawak Malay culture and language have their own proverbs which are yet to be properly collected, documented, analyzed and described. 
This paper, arising from a larger research project, is the first attempt to collect, document, describe and analyze the Sarawak Malays' proverbs. The research has successfully collected, described as well as analyzed 1373 verses of proverbs.

In this paper I will focus on the definitions of the proverbs, the analysis of the proverbs by applying Sperber and Wilson's Relevance Theory, and the functions as well as uses of the proverbs among the Sarawak Malays community. I will also touch on who are the Sarawak Malays as a brief introduction to the community. The last part of my paper will include several conclusions and recommendations for further research on the Sarawak Malays' proverbs.

I earnestly hope that, by presenting this paper pertaining to the functions and uses of Sarawak Malays' proverbs, the community will be well-known, and will indeed excite the interest of the local and foreign researchers towards the community, especially in the domain of oral tradition.

\section{Sarawak Malays Community in Brief}

In order to study the traditional literature of the Malay of Sarawak, the oral tradition in particular, it is imperative to have a glimpse of the community's culture and language as both aspects are the main sources of my data on their proverbs.

In general, the Malays of Sarawak are different from the other Malays in other states in Malaysia, except for the fact that they are all Muslims. They speak their own language, which is Sarawak Malay dialect or locally known as basa Melayu Sarawak. In term of culture, they practice their own culture that in one way or another, do have some similarities with the Malays elsewhere in Malaysia.

Actually, basa Melayu Sarawak is the lingua franca for the multi-ethnic, multi-dialect and multi-cultural communities in Sarawak. According to Article 160 of the Federal Constitution, a Malay is defined as a person who professes the Muslim religion, habitually speaks Malay, and conforms to Malay customs. In the Sarawak Constitution, by contrast, the term Malay is less elaborate as they are merely on of the communities mentioned in a long list of natives originated from Sarawak, but, due to the fact that they profess the Muslim religion, habitually speak Malay, and conform to Malay customs, herewith the Malays of Sarawak are legally regarded as Malay as per the Federal Constitution.

In addition to the clause of Article 160 mentioned above, Abang Yusuf Puteh (1998:2-3) elaborates that:

"An examination of the term 'Malay' in Sarawak would invariably bring us to two interesting anthropological processes of conversion: firstly, from non-Malay to Malay, and secondly, from a Malay to Malay. In Sarawak, the phrase masuk Melayu (which is literally translates as to enter Malay), culturally and legally means a non-Malay to become and accepted as a Malay. It is a process for a non-Muslim to convert to Islam, usually upon marriage. The terminology masuk Melayu is of course a misnomer but which has been accepted throughout the ages. The children of a Malay from the masuk Melayu process are firstly Muslims and secondly registered as Malays. For all practical purposes the convert is a Malay whose rights include the eligibility to buy and own native lands."

Besides Islam, the main characteristic that distinctively differentiate them from the other groups which were considered as the Malay of Sarawak such as those who have converted to Muslim as well as the Arabs, Kedayan, Javanese, Bugis etc., is their language. Awang Hasmadi (1998) quoted Harrisson (1970:132) as saying:

"Istilah Melayu dan kaum Islam Sarawak sering bertukar ganti penggunaannya. Oleh yang demikian ada kalanya pengertian Melayu juga merujuk kepada penduduk Sarawak yang lain yang beragama Islam seperti kaum Melanau Islam." (The usage of the term Malay and Sarawak Muslims are regularly inter-changeable. As such, sometimes the meaning of Malay is used to refer to those Sarawakians who are Muslims such as the Muslim Melanaus.) Hence, the term Malay used in this paper as defined above.

\section{Definitions of Proverbs}

One of the Sarawak Malays' oral tradition which authenticate the poetic, beauty and rhythmic nature of their language are the proverbs or peribahasa. According to Mieder (2004), generally, proverbs are known as short sayings of the 
folk which contain wisdom, truth, morals and traditional views in the form of metaphors, or fixed and memorable forms which are handed down from generation to generation.

Thomas Fuller as quoted by Richard Winstedt (1957) defined a proverb as "much matter decocted into a few words", meanwhile, Cervantes defined a proverb as "short sentences drawn from long experience".

For the purpose of this paper, and due to the fact that the Sarawak Malays share common cultural and religious values as well as language similarities with the Malays in Peninsular Malaysia, the interpretation of proverb as defined by Za'ba (1962:165) as follows will be the main reference:

Peribahasa itu ialah segala susunan cakap yang pendek yang telah melekat di mulut orang ramai semenjak beberapa lama oleh sebab sedap dan bijak perkataannnya, luas dan benar tujuannya, dipakai akan dia jadi sebutan oleh orang sebagai bandingan, teladan dan pengajaran. Maka ialah juga yang dikatakan bidalan, pepatah, perbilangan dan perumpamaan kerana tiap-tiap satu ini cakap yang mengandungi segala sifat peribahasa yang telah disebutkan itu.

(A proverb refers to all sequences of short sayings commonly used among the people from years ago due to the beauty and wisdom of the words, the breadth and truth of its purpose, these sayings were used by the people as comparison, example and lesson. Thus, it is also known as aphorism, adage, saying and maxim as each of these sayings demonstrate every characteristic of the proverbs mentioned.)

For the sake of retaining the accuracy of the meanings of the terms, in this paper the Malay terms of pepatah or bidalan, perumpamaan, and simpulan bahasa rather than the translated equivalent in English will be used. The term 'proverbs' or peribahasa therefore refers to all the generic terms of pepatah or bidalan, perumpamaan, perbilanganand simpulan bahasa.

\section{Sources of Data}

1. The main sources of the Sarawak Malays proverbs in this research are:

2. The Malays of Sarawak: A Socio-Political Portrait (Abang Yusuf Puteh, 1998)

3. Adat Perkahwinan Orang Melayu Sarawak Edisi Kedua (Abang Yusuf Puteh, 2008)

4. Several interviews with two reliable informants who are well-versed in the Malays of Sarawak culture, traditions and oral tradition, particularly pantun. One of the informants was an ex-teacher who has published three books on Sarawak Malays pantun. The other one was a Quran teacher as well as an ex-bilal.

\section{Types of Sarawak Malay Proverbs}

By applying the interpretation of Za'ba (1962) as mentioned earlier, this research discovered that the proverbs of the Sarawak Malay comprised of:

1. Pepatah or bidalan (A proverb which has a single meaning).

2. Perumpamaan (A proverb which has a double meaning).

3. Simpulan Bahasa(A phrase comprising of two or more words and established by usage and not immediately comprehensible from the words used).

4. Values of Beliefs.

5. Two-line pantoum.

The summary of the findings of this research is stated in

Table 1. The number of proverbs according to types

\begin{tabular}{|c|c|c|}
\hline NO. & TYPES OF PROVERBS & TOTAL \\
\hline 1. & Pepatah atau Bidalan & 266 \\
\hline 2. & Perumpamaan & 91 \\
\hline
\end{tabular}




\begin{tabular}{|c|c|c|}
\hline 3. & Simpulan Bahasa & 964 \\
\hline 4. & Nilai Kepercayaan & 46 \\
\hline 5. & Pantun Dua Kerat & 6 \\
\hline 6. & Perbilangan & 0 \\
\hline 7. & Lidah pendeta & 0 \\
\hline \multicolumn{2}{|r|}{} & $\mathbf{1 3 7 3}$ \\
\hline
\end{tabular}

The findings of this research also showed that there are no proverbs that can be categorized as perbilangan or a proverb comprising of two lines or more whereby its content might become a rule, law or advice that might become a guide. This research also found that there are no proverbs that can be considered as lidah pendeta. Besides the findings stated in Table 1 above, this research also uncovered that they are six types of simpulan bahasa as shown in Table 2 below. The simpulan bahasa was categorized into six types based on word class used in the proverbs, namely noun, verb, adjective, proper noun, function word and preposition.

Table 2. The Number of Verses Based On Word Class

\begin{tabular}{|l|l|l|}
\hline NO. & SIMPULAN BAHASA BASED ON WORD CLASS & TOTAL \\
\hline 1. & Noun & 387 \\
\hline 2. & Verb & 324 \\
\hline 3. & Adjective & 223 \\
\hline 4. & Proper Noun & 18 \\
\hline 5. & Function Word & 5 \\
\hline 6. & Preposition & 7 \\
\hline & & $\mathbf{9 6 4}$ \\
\hline
\end{tabular}

The findings of this research pertaining to Sarawak Malay proverbs, especially on the number and types of proverbs as well as the description of the meanings, is the first of its kind.

\section{Analysis Based on Relevance Theory}

The application of Sperber and Wilson's Relevance Theory (1995) for this research is due to the fact that proverbs played a pertinent role in the communication process, especially among the traditional Sarawak Malays community. Besides that,proverbs are parts of the oral tradition that are commonly observed among the community.

According to Relevance Theory, communication is a process which involves two distinctive mechanisms of information processing devices, namely involving the modification of the physical environment of the hearer, and the creating or building of representations which are similar to the ones of the hearer.

Meaning to say, Sperber and Wilson (1995) stressed that, in an oral communication the hearer usually tries to modify the hearer's environment in order to entertain some certain thoughts that the speaker wants to share with the hearer. Hence, if that is the case, the second device will create or build several representations that are similar to the ones of the hearer. The two approaches of Sperber and Wilson as mentioned above are indeed suggesting two pragmatic questions. Firstly, the question of "what is communicated ?" and secondly "how the objective of the communication is achieved?"

Pragmatically, this research applied Sperber and Wilson's Relevance Theory to analyze proverbs based on the justification that the meanings of the proverb fundamentally depends on the identification of the speaker's intention, and the inference of the implicit communication rather than decoding what is explicitly articulated. Nevertheless, this 
research also took in account the proposed definition of the term 'relevance' suggested by Sperber and Wilson (1995): "an assumption is relevant in a context if and only the assumption has certain contextual effect in that context". To this extent their definition of the term "relevance" is pragmatic to be applied for the analysis of Sarawak Malays proverbs as having certain contextual effect is the essential condition for the relevance of a proverb.

\section{Functions of Proverbs Among the Sarawak Malays Community}

Proverbs as part of the oral tradition of the Malays, including the Malays of Sarawak, play a significant role in the communication process among the community. Furthermore, proverbs are the product of language that contains two main aspects, the cognitive as well as emotive aspects.

Iman Budi Santosa (2016:viii) asserted the functions and uses of the proverbs as:

Peribahasa atau sering disebut aforisme, wujudnya adalah kelompok kata atau kalimat yang susunannya tetap untuk mengungkapkan pernyataan tertentu. Isinya adalah perbandingan, perumpamaan, nasihat, prinsip hidup, aturan tingkah laku, baik yang dipujikan atau dilarang dalam tradisi setempat. Konstruksi kalimat pun umumnya dibuat singkat, padat, puitis, agar memiliki daya tarik sehingga mudah dihapal dan diingat oleh masyarakatnya. Dalam sejarahnya, peribahasa yang berisi nasihat lahir dan digali dari simpul-simpul pandangan hidup yang bersumber pada agama, kepercayaan, mitos, religi, falsafah, serta ajaran para cerdik pandai/pujangga/wali/raja/datu di masa lalu yang terbukti ampuh menjadi pedoman hidup mereka.

(Proverb or usually referred to as aphorism, its existence are in the form of words cluster or sentences which have a fixed sequence for articulating certain expressions. They contain comparisons, maxims, advice, principles of life, order of behavior, whether honored or prohibited within the local tradition.)

Generally, the construction of sentence is also short, concise, poetical, so that it possessed the power of attraction until it is easy to be memorized and remembered by its community. In its history, the proverb contained advice which originated and were unearthed from the inferences view of life rooted from the religion, beliefs, myth, philosophy, as well as the teachings of the intelligentsia / literati/saint/king/dignitary years ago that has been proven purposeful as their guidance of life.)

Pertaining to the functions and uses of the Malay proverbs of Sarawak, this research has focused on the analysis of the literary styles of the proverbs. The analysis proved that its literary style contains aesthetic and artistic values. Both values are capable in arousing numerous feelings of their readers and hearers, and simultaneously increase their knowledge as well as stimulating their power of thinking.

This research also found that the dominant literary style of the proverbs are metaphors as well as figurative, and which are mainly functioning as innuendo, sarcasm, insinuation and mockery in an indirect manner. The research also proved that, the proverbs functioned as a lesson to their readers and hearers.

As mentioned earlier, the functions of the proverbs are to impart lessons, advice, comments and criticism in a refined and well-mannered way. The analysis of the 1373 collected Sarawak Malay proverbs discovered the existence of several elements of lessons, advices, comments and criticisms such as follows:

1. Courteous (berbudi bahasa).

2. Cautious (berwaspada).

3. Cooperative (saling bekerjasama).

4. Good at keeping secret (tahan menyimpan rahsia).

5. Not to behave boastfully, greedily, enviously, maliciously, insolently and so on (tidak bersikap sombong atau meninggi diri, tidak tamak, tidak iri hati, dan tidak mengumpat, tidak menghina dan sebagainya).

The proverb jaga mulut (keep your mouth) which means to be guarded when talking, for instance, is a reminder for everyone to be courteous in order to ensure mutual relationship among the members of society, and simultaneously, to avoid offending or hurting their feelings. 
Meanwhile, buah masak belum tentu manis (ripe fruit not necessarily sweet) which means those who are nice-looking are not necessarily having a good behavior; this reminds us to be constantly cautious, and not easily deceived by what we see, by their lovely appealing or their beautiful appearances. In short, not to judge a book by its cover.

They are proverbs that contained advice that remind us about the importance of mutual understanding, mutual cooperation and mutual responsibility among the community to ensure peace and harmony in the society. The proverb berat sama dipikol ringan samadijinjeng (bear the same weight the same light) is one of the example.

This research also revealed the element of advice that requires us to be good at keeping secret, and refrain from disclosing it in order not to cause harm or virulence to others as well to assure that he or she is faithful and sincere to each other. One of such proverb is sak pecah di perut jangan pecah di mulut (let burst in the stomach do not burst in the mouth).

Besides the elements of advice and lesson of the proverbs as described earlier, this research also found out that they are proverbs that advised us not to disgrace our own family, and so on as such an act will only insult and humiliate ourselves. An example of such proverb is jangan meludah ke langit kelak nimpak muka dirik empun (don't spit into the sky will fall into his own face) which means do not disgrace your own parents or your family members as it will disgrace yourselves.

Other functions and uses of the proverbs discovered from this research are pertaining to the ethos and values which are related to their function as elements of didactics in line with Harun Mat Piah (1989) view that like pantun and teromba, the proverb also depicts the ethos and values of the community. These ethos and values normally become the norms of the community concerned, and not excluding the Malay of Sarawak community.

The analysis of the proverbs of the Malay of Sarawak, surfaced that the elements of ethos and values also existed as stated below:

1. Courteous and meritorious (berbudi dan berjasa).

2. Humble (merendah diri

3. Hardworking (bekerja kuat)

4. Thrifty (berjimat cermat)

5. Loyal (taat setia)

6. Respecting the laws (Menghormati Undang-undang)

The proverb ada padi ada beras, ada budi ada balas (there is no rice paddy cultivation there is no reply) for instance, reflects the Malays of Sarawak emphasis on the importance of gratitude and good deeds among its community members. Being grateful is part of the dominant and integral cultural values among the Malays of Sarawak community, and simultaneously it binds them to much larger values. Being grateful is also not merely giving and receiving in terms of material, however, it also pertinent to other matters pertaining to the ethic, moral, cultivated manners as well as customs of the community.

The Malays of Sarawak do not tolerate those who are arrogant or snobbish as well as boastful. Kambin gambong (snooty goat) is one of the examples of the proverb that describe a person who arrogant or snobbish, and proud or boastful. This also resembles the snooty and fierce appearance of the goat. Another proverb that describe a person who is boastful is besar kelakar (big words or brag), and the Malays dislike such behavior.

One of the proverbs that reflect the antipathy of the Sarawak Malays towards an act of extravagant is tin-tin telinga tikus, sak gentin jangan putus which literally means no matter how tight it is just don't let it break. This proverb reminds the members of the community to be thrifty in their spending, and to be frugal in everything they do.

The Sarawak Malay community also lays a great importance on the values of responsibility and accountability. Every member of the society is required to be responsible and accountable for whatever deeds they commit. Nevertheless, pertaining to the issue of reliability, particularly regarding honor and self-respect, the words or confession of a woman is more reliable. The proverb banyak malu kepada perempuan sedikit malu kepada laki-laki (a woman more reliable than man) describes that the evidence or the confession made by a woman regarding the wrong deeds of a man towards her such as molesting, illicit sexual intercourse or adultery, is more reliable. That proverb can also be interpreted, due 
to the fact that she is a woman she is the one who will bear the shame more than the man in certain cases especially pertaining to extramarital affairs.

This research also showed that there are certain proverbs which require every members of the community to be a responsible person. Those who commit wrongdoings or bad deeds should be held responsible for what they did. They should not lepas tangan (wash their hands clean) of what they did, and instead they should be berani nebang berani mikol (brave brave bear felling). In other words, he or she should be berani buat berani tanggung (dare to take bold responsibilities).

\section{Uses of Sarawak Malays Proverbs}

The uses of proverbs as mentioned earlier was defined as a way of saying something implicitly rather than explicitly supporting one's arguments using a popular wisdom. Moreover, proverbs are full of metaphors as well as considered as part of figurative language due to the fact they are an indirect way of conveying a set of assumptions pertaining to shared thoughts between the hearer and the speaker rather than stating or conveying them directly.

Proverb is also a unique feature of the Sarawak Malay language in which message, advice, lesson, comment, remark and criticism is indirectly communicated through figurative language and metaphoric phrases. Notwithstanding, the uses of proverb in communication may precipitate misinterpretation as well as misconception and confusion among the hearers if they are not familiar with the phrases as they contained implicit meanings that need to be interpreted wisely.

a. According to Za'ba (1962:165), they are uses of peribahasa or proverbs such as:

b. Menghiasi karangan atau percakapan (decorating essay or conversation).

c. Menguatkan tujuan karangan atau percakapan (enhancing the goals of essay or conversation)

d. Dijadikan pedoman hidup kerana isinya yang besar dan luas (used as a guide of life because the content is large and wide-reaching).

Based on Za'ba's definition on the uses of the Malay proverbs, this research revealed that, they are three main uses of the Sarawak Malays proverbs such as stated below:

\subsection{Advice and Lessons}

Most of the proverbs found in this research are contemplated as an advice to the hearers rather than aimed to criticize them. Such proverbs also served as a lesson to the hearers in order ensure that they will be more cautious in the future, and refrain themselves in repeating such mistake and so on. As an illustration of advice and lesson, we can see two examples of proverbs below:

a. Besar pasak dari tiang (unbalanced budgeting) which means more spending compared to income). This proverb served as an advice so that the hearer will manage his or her income wisely in order to avoid overspending

b. Udah beruban masih berolah (literally gray but still throwing a tantrum) is some sort of a lesson for an old man or woman not to misbehave as if he or she is still juvenile. In other words, the elders should show good examples to the young ones.

\subsection{Reminders and Warnings}

This research also revealed that, the proverbs also aim to give warning and reminder to the hearers in order to warn or prevent them from doing something which may cause problem or danger. The examples of such proverb are as follow:

a. Diam-diam lepuk (silent silent lionfish) which means enemy or someone who is taciturn should not be taken lightly. This proverb reminds and warns the hearer to be cautious always in order not to be deceived by the appearance of a taciturn person. 
b. Sik pisang bebuah duak kali (once bitten twice shy) which means once being cheated, deceived or suffered a loss, he or she should be daunted or discouraged and learn non's lesson. This proverb is a reminder and warning to the hearer in order not to repeat the same mistake as well as not to be cheated or deceived twice for the same reasons and so on.

\subsection{Criticism}

The analysis of the Sarawak Malays proverbs disclosed that, most of the times, the speaker emits or utters a proverb with the aim of criticizing the hearer or accusing or ridiculing the hearer. The following proverbs are the illustration of this function.

a) Berani kesak (brave weaver ant) which means a person who is only brave or daring such as when fighting, when he or she is with a group of people. This proverb criticizes the hearer who is in fact a coward, and not daring to challenge others face to face, and when he or she is alone.

b) Jaik perut (rotten stomach) which suggests that the bad qualities of a person are not from the heart but from the bowels. According to Abang Yusuf Puteh (1998:178), one possibility of its origin may be the reference to faeces in the stomach. This proverb is criticizing the hearer who is having a rotten heart, and bad attention which are not healthy for the establishment of a relationship or for the intercommunication among the community.

\section{Conclusion}

As I have observed and analyzed, the existence of the long list of Sarawak Malays proverbs which I have collected, described and documented through this research, is a contribution to the Malay civilization, especially in the field of oral tradition.

This study showed that, the proverbs play an important role in the traditional communication process among the Sarawak Malays community which are not popularly known among previous researchers.

The analysis of the proverbs revealed that they described the good and bad behavior of the Malay community. In other words, the functions and uses of the proverbs in the Sarawak Malays community are to describe a man or woman's behavior and attitude such as terms of honor.

To conclude, this research, the first of its kind as far as the Sarawak Malays proverbs are concerned, is a stepping stone for further research in the field of oral tradition among the Sarawak Malays, in the domain of proverbs in particular.

\section{References}

1. Abang Yusof Puteh. The Malay Mind. Shobra Peblications Sdn. Bhd., Kuching, Sarawak.1997.

2. Abang Yusof Puteh.The Malays of Sarawak:A Socio-Political Portrait.Shobra Publications Sdn. Bhd., Kuching, Sarawak.1998.

3. Abang Yusuf Puteh. A Profile of Sarawak Malays. Penerbit Universiti Pendidikan Sultan Idris, Tanjong Malim. 2005.

4. Abang Yusuf Puteh. Adat Perkahwinan Orang Melayu Sarawak Edisi Kedua. Dewan Bahasa dan Pustaka, Kuala Lumpur. 2008.

5. Awang Hasmadi Awang Mois \& Sanib Said (Penyunting). Masyarakat Melayu Sarawak: Himpunan Kertas Seminat Budaya Melayu II. Yayasan Budaya Melayu Sarawak, Kuching. 1998.

6. Harun Mat Piah. Puisi Melayu Tradisional : Satu Pembicaraan Genre dan Fungsi. Dewan Bahasa dan Pustaka, Kuala Lumpur. 1989.

7. Iman Budhi Santosa. Peribahasa Nusantara, Mata Air Kearifan Bangsa. DPP PDI Perjuangan, Jl. Diponegoro, Menteng, Jakarta. 2016.

8. R.O. Winstedt. Malay Proverbs. London, Murray.1967.

9. Sperber,D. \& Wilson,D. Postface to the Second Edition of Relevance:Communication and Cognition. Oxford:Blackwell. 1995. 